(C) 2017

Писаренко П. В., доктор сільськогосподарських наук, професор, Самойлік М. С., доктор економічних наук

Полтавська державна аграрна академія

\title{
МУЛЬТИФУНКЦІОНАЛЬНЕ МОДЕЛЮВАННЯ РЕГІОНАЛЬНОЇ СИСТЕМИ УПРАВЛІННЯ ТВЕРДИМИ ВІДХОДАМИ З УРАХУВАННЯМ СИНЕРГІЧНОГО ЕФЕКТУ
}

У статті сформульовано балансову схему життєвого ичиклу твердих відходів регіону, щчо дало змогу розробити еколого-економічну модель оптимального управління сферою поводження з відходами та визначити оптимізаційні сценарії управління даною сферою за теоретично оптимальних значень параметрів. На основі моделі управління сферою поводження з твердими відходами сформовано алгоритм визначення оптимальних управлінських стратегій $i$ механізмів їх реалізації, який дає змогу вирімувати поставлені задачі оптимізації розвитку сфери поводження з відходами в разі заданої множини змінних $i$ параметрів стану системи для конкретного типу життєвого ииклу даної сфери. Розроблена модель має множину допустимих рішень $i$, відповідно, пропонує вибір найкрамсого з них з урахуванням циільових функиій. Обгрунтовано практичне використання даної моделі на прикладі Полтавської області на основі оптимізації трьох ичільових функиій: екологічного ризику здоров'ю населення від сфери поводження $з$ твердими відходами; максимамізації прибутку за мінімальних вкладень у дану сферу; енергоємності системи поводження з відходами.

Ключові слова: сфера поводження з твердими відходами, оптимізачійна модель, регіон, цілььові функції.

Постановка проблеми. Проблема відходів одна 3 найбільш важливих еколого-економічних та соціальних проблем регіонального розвитку. Одна 3 головних причин погіршення якості навколишнього середовища та виникнення зон «екологічного лиха» полягає в тому, що величезні кількості речовин витягнуті із землі, перетворені в нові з'єднання і розсіяні в довкіллі без урахування того факту, що «все кудись дівається». У результаті великі кількості речовин нерідко накопичуються в тих місцях, де, за природою, ix не повинно бути. Біосфера функціонує на основі замкнутих екологічних циклів речовин i енергії, а виробництво відходів - це виняткова особливість цивілізації.

Однією із проблем сучасної науки, що в подальшому призводить до екологічних проблем суспільства, $є$ те, що розуміння процесів, які відбуваються в екосфері, у сучасних фахівців досить ускладнене, адже в результаті багаторічного процесу диференціації знань, увійшло до звички розглядати окремо взяті, одиничні події, кожне 3 яких має якусь причину. У цьому аспекті актуалізується питання формування інноваційних підходів до системи управління твердими відходами (TB), визначення оптимізаційних моделей та механізмів підтримання прийняття управлінських рішень на основі методології системного аналізу з урахуванням екологічних, технологічних і соціально-економічних умов і синергічного ефекту від функціонування такої системи на регіональному рівні.

Аналіз останніх досліджень і публікацій, у яких започатковано розв'язання проблеми. Серед досліджень, присвячених різним аспектам удосконалення системи управління сферою поводження 3 відходами та залучення їх у господарський обіг, необхідно виділити роботи О. Бондаря, Г. Виговської, В. Вагіна, Т. Галушкіної, Б. Горлицького, С. Ілляшенка, Л. Мельника, В. Міщенка, С. Тяглова, Є. Рюміної, В. Пірса, І. Синякевича, I. Уолтера та інших. Проте питання удосконалення системи регіонального управління сфери поводження з ТВ на основі оптимізаційного моделювання даної сфери недостатньо відпрацьовані. Відмічаючи велику кількість підходів і прикладних досліджень по розкриттю окремих питань проблематики сфери поводження 3 ТВ, слід зазначити, що багатоаспектний аналіз системи поводження з ТВ і розробка на цій основі оптимізаційних економікоекологічних моделей управління, алгоритмів прийняття рішень у даній сфері, до сих пір зостаються актуальними для наукового пошуку.

Мета і завдання досліджень: розробити та науково обгрунтувати оптимізаційну модель управління системою поводження 3 твердими відходами регіону, на основі якої сформулювати алгоритм прийняття рішень у сфері поводження з ТВ для збільшення ресурсозабезпечення регіону та визначити пріоритетні задачі управління даною сферою.

Матеріали і методи досліджень. Враховуючи, що проблематика поводження з відходами виходить 


\section{СІЛЬСЬКЕ ГОСПОДАРСТВО. ЕКОЛОГІЯ}

за межі суто екологічних чи економічних досліджень і знаходить відображення в системі фундаментальних та прикладних наук, іiі методологія має базуватися на багатодисциплінарності і цілісному світогляді. У даному контексті традиційні підходи до управління ТВ, що передбачали моделювання системи на основі вивчення ㄲi елементів, є абсолютно неприйнятними до складних систем «природа - суспільство - людина», та потребують формування нового підходу, що грунтується на інтеграції принципів системного підходу (який у якості методичного інструментарію включає системний аналіз, метод систематизації) 3 іншими науковими підходами та точками зору.

Тому методологічний базис дослідження питань управління ТВ, що грунтується на системному аналізі, в авторському розумінні доповнено: синергетичним підходом, в основі якого лежить ідея самоорганізації систем, тобто прагнення системи до самозбереження, яке проявляється у виділенні деякої області стійкості, де система знаходиться у рівноважному стані та супроводжується мінімальною втратою енергії; цільовим, ресурсним та стратегічним підходами; аксіологічним підходом; функціональним підходом (поєднує функціональноорієнтований і процесорно-орієнтований підходи); поєднанням метафізичного та діалектичного методів пізнання під час дослідження питань управління ТВ. Реалізація ефективного управління ТВ відповідно до біосферної парадигми суспільного розвитку повинна включати не просто захист навколишнього природного середовища, але й комплекс нових підходів і концепцій управління щодо інтеграції інтересів суспільства у систему стратегічних цільових орієнтирів екологоорієнтованого розвитку регіонів.

Результати досліджень. Технологічна система поводження 3 ТВ $\epsilon$ складною взаємопов'язаною сіткою джерел утворення відходів, технологічних операцій на кожному етапі життєвого циклу і об'єктів поводження з урахуванням їх взаємного розташування на певній території, наявності транспортного з'єднання i напрямків руху потоків відходів. Основні елементи технологій поводження 3 ТВ відповідають основним етапам життєвого циклу ТВ: утворення; збір, накопичення і тимчасове зберігання (формування одного або декількох потоків відходів 3 певними характеристиками); транспортування (рух потоків відходів); утилізація або видалення відходів (зміна потоків і кінцеве розміщення відходів). Водночас функціонально-предметна мо- дель управління твердими відходами, з урахуванням вище наведених методичних підходів, має бути орієнтована на максимально повне врахування принципів комплексного управління відходами та включати балансові схеми життєвого циклу сировини та енергії у замкнутому циклі використання матеріально-енергетичних ресурсів регіону. Таким чином теоретико-модельна конструкція функціонально-предметних взаємозв'язків і взаємозалежностей між основними ланками системи управління ТВ грунтується на двох взаємодоповнюючих процесах: 1) оптимальне використання первинної сировини та мінімізація утворення відходів; 2) максимальне повернення матеріальних та енергетичних вторинних ресурсів у господарський обіг. Виходячи iз цього, баланс використання первинних та вторинних ресурсів у регіоні наведено на рис. 1. На рисунку 1 прийнято такі позначення:

$$
X=\left\{X^{y}, X^{3}, X^{H}, X^{P}, X^{E}, X^{M}, X^{I}, X^{B}\right\}-\text { множина }
$$
всіх змінних стану сфери поводження з відходами у регіоні: утворення, збір, несанкціоноване видалення, сортування і переробка, сортування i компостування, сортування і спалювання, видалення на полігони, поводження із вторсировиною у регіоні;

$X_{\Sigma}^{y}, X_{\Sigma}^{g}, X_{\Sigma}^{H}, X_{\Sigma}^{F}, X_{\Sigma}^{E}, X_{\Sigma}^{M}, X_{\Sigma}^{I I}, X_{\Sigma}^{B}-$ cумарна кількість відходів, утворених у регіоні; зібраних по всіх пунктах збору; незаконно розміщених на несанкціонованих звалищах; відсортованих i перероблених на сміттєпереробних заводах, компостних заводах, спалювальних заводах; відсортованих і видалених на полігонах та санкціонованих звалищах відходів регіону; сумарна кількість вторсировини, зібраної у регіоні.

Джерела утворення відходів умовно поділяються на об'єкти житлового фонду $\left(\sum_{s^{N}=1}^{n^{Y_{N}} X_{s_{N}}^{y}}\right)$, підприємства, організації та установи $\left(\sum_{s^{p}=1}^{n^{\gamma_{F}}} X_{s^{p}}^{y}\right)$, а також об'єкти суспільного призначення та вуличне сміття $\left(\sum_{\Sigma^{c} \eta^{y_{c}}}^{x_{s}} x_{s}^{y}\right)$. Далі відходи збираються унітарно $\left(\sum_{i^{R}=1}^{n^{3} R} X_{i^{R}}^{g}\right)$ або селективно $\left(\sum_{i^{U}=1}^{n^{3} U} X_{i}^{g}\right)$. При цьому роздільний збір може бути однаковим у регіоні (дво-, трифракційний тощо) або різним

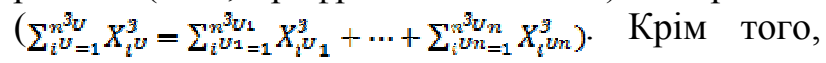
частину вторинних ресурсів населення може здавати у пункти прийому вторсировини

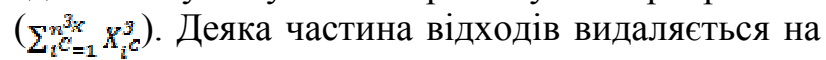
несанкціоновані звалища $\left(\sum_{m=1}^{n^{H}} X_{m}^{H}\right)$. 


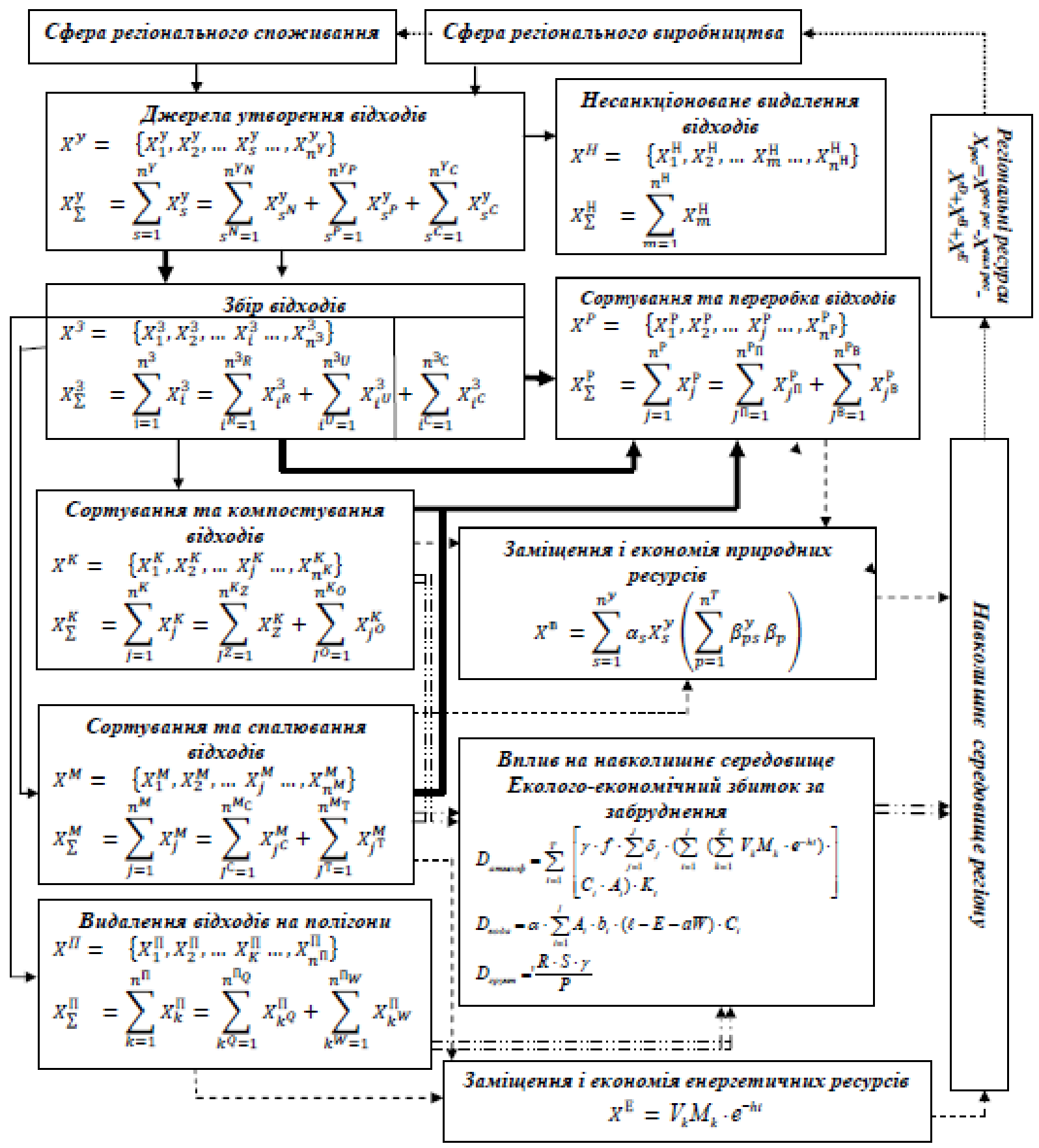

Рис. 1. Балансова схема эниттевого циклу первинних та вторинних ресурсів регіону (складено авторами з використанням [1])

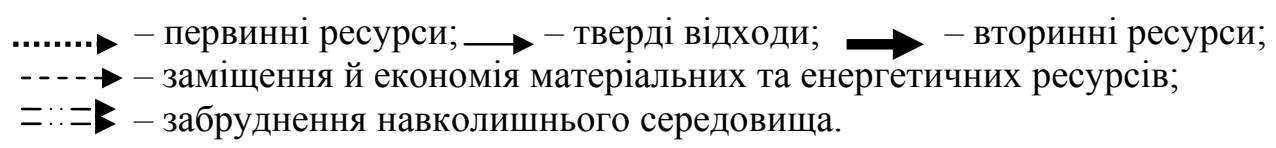

При цьому можливі два варіанти використання власником вилучених вторресурсів. Перший власник вторинних ресурсів здає їх на пункти збору, й отриманий дохід є його власністю. Інший - направляє вторресурси на спеціалізовані пункти збору (роздільний збір), і дохід від їх ре- алізації отримує організація, яка збирає їх від імені регіону. Як стимулюючі заходи регіон може знижувати розміри платежів за приймання відсортованих відходів, здійснювати агітаційну роботу. Тоді відповідно вилучені вторресурси власник розділяє таким чином: 


$$
X_{s p}^{\mathrm{VBH}}=\alpha_{s} \alpha_{s p}^{B} \beta_{n s}^{y} \beta_{p} X_{s}^{y}=\alpha_{s p}^{B} X_{s p}^{\mathrm{VB}}
$$

де $X_{s p}^{\text {yBII }}$ - кількість вторресурсів, $p$-го від $s$-го джерела, що направляється на всі пункти збору вторсировини; $\alpha_{s}-$ коефіцієнт сортованості відходів, $\boldsymbol{\beta}_{p s}^{y}$ - коефіцієнт вилучення $p$-го типу вторресурсів із відходів, що підлягають сортуванню, у $s$-го власника відходів; $\beta_{p}-$ потенційний середній уміст $p$-го типу вторресурсів у відходах регіону; $\alpha_{s p}^{B}-$ коефіцієнт поділу вторресурсів $p$-го

$$
\begin{aligned}
& X_{i}^{B}=\sum_{j=1}^{n_{P}} X_{i j}^{3 \mathrm{P}}+\sum_{j=1}^{n_{M}} X_{i j}^{3 M}+\sum_{j=1}^{n_{K}} X_{i j}^{3 K}+\sum_{k=1}^{n_{\Pi}} X_{i j}^{3 \Pi}+\sum_{j=1}^{n_{B}} X_{i j}^{3 B}=X_{i}^{3 P}+X_{i}^{3 M}+X_{i}^{3 K}+ \\
& +X_{k}^{\mathrm{MI}}+X_{i}^{B}
\end{aligned}
$$

де $X_{i j}^{g p}, X_{i j}^{9 M}, X_{i f}^{9 R}, X_{i k}^{3 / 7}, X_{i l}^{9 B}$ - потоки відходів з $i$-го пункту збору на $j$-й завод 3 перероблення, компостування, спалювання, $\kappa$-й полігон, $l$-й пункт переробки вторсировини.

Рівняння балансів для $j$-го заводу сортування i переробки відходів (3); спалювання відходів (4); ïx компостування (5); видалення відходів на по-

лігонах і звалищах (6), на несанкціоновані звалища (7) можна подати так:

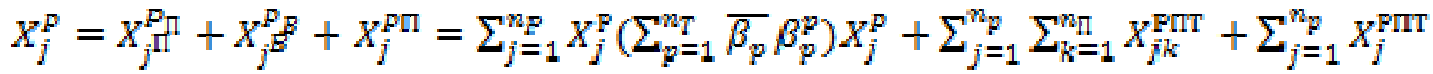

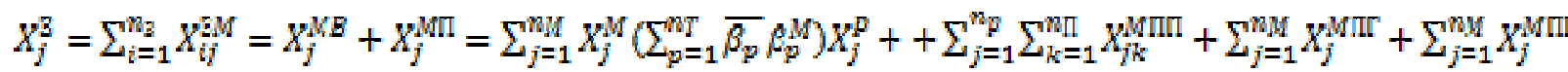

$$
\begin{aligned}
& X_{j}^{K}=\sum_{i=1}^{n_{n}} X_{i j}^{3 K}=X^{K B}+X^{K K}+X^{K \Pi \Pi}+X^{K \Pi \Gamma}+X^{K \Pi F}=\sum_{j=1}^{n_{K}} X_{j}^{M}\left(\sum_{p=1}^{n_{T}} \overline{\beta_{p}} \beta_{p}^{K}\right)+ \\
& \sum_{j=1}^{n_{K}} X_{j}^{K K}+\sum_{j=1}^{n_{K}} \sum_{k=1}^{n_{\Pi}} X_{j k}^{K \Pi \circ}+\sum_{j=1}^{n_{K}} X_{j}^{K M \Gamma}+\sum_{j=1}^{n_{K}} X_{j}^{K I I P}
\end{aligned}
$$

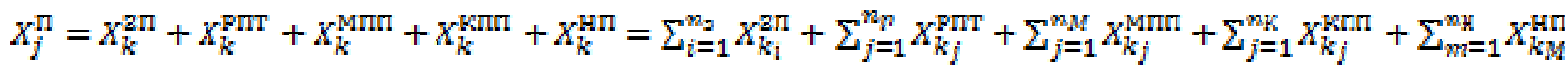

$$
\begin{aligned}
& X_{m}^{H}=X_{m}^{3 H}=\Sigma_{S=1}^{n_{j}} X_{m S}^{3 H}=X_{m}^{H S}+X_{m}^{H K}
\end{aligned}
$$

де $X_{F_{H}^{H_{H}}}^{P_{R}}, X_{j^{B}}^{P_{B}}$ - потік вторсировини на переробку самим власником або на переробку іншому власникові; $X_{j}^{P H}$ - потік залишків відходів $3 j$-го заводу з перероблення на видалення (ущільнюють та отримують тверду складову $X_{j}^{P I T}$ і рідку $\left.X_{j}^{P M P}\right) ; \beta_{p j}{ }^{P}$ - коефіціснт вилучення $p$-го типу вторсировини на $j$-му сміттєпереробному заводі; $\overline{\beta_{p}}-$ середній уміст $p$-го типу вторсировини у регіоні; $X_{j}^{9 M}, X_{j}^{M R}, X_{j}^{M I}-$ потік відходів зі всіх пунктів збору на $j$-й завод зі спалювання, потоки відходів з $j$-го заводу зі спалювання на всі заводи 3 перероблення та полігони відходів; $\beta_{p j}^{M}$ - коефіцієнт вилучення $p$-го типу вторсировини на $j$-му заводі зі спалювання відходів; $\sum_{I^{c}=1}^{n^{n c}} X_{j^{c}}^{n}-$ спалювання відходів із доступом повітря; $\Sigma_{f^{T}=1}^{n_{T}^{M T}} X_{j^{T}}^{M}-$ піролізні установки; $X_{f}^{M T R T}, X_{f}^{M T T}, X_{f}^{M T P}$ - потоки відходів з $j$-го заводу зі спалювання: зола на полігони відходів, газові відходи у фільтри і теж відповідно на полігони, рідкі відходи у систему ка-

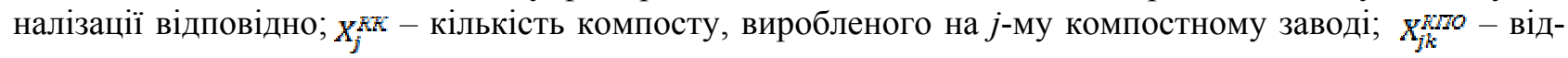

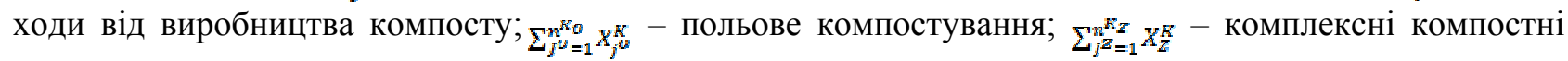
заводи; $X_{K}^{3 \Pi}, X_{K}^{P M T}, X_{K}^{M I I T}, X_{K}^{E I I}, X_{K}^{H I I}-$ потоки відходів на $\kappa$-й полігон; $X_{m}^{3 H}$ - потік відходів від усіх їх власників на несанкціоноване видалення; $X_{m}^{H 3}$ - залишок відходів на $m$-му несанкціонованому звалищі; $X_{m}^{\text {FII }}$ - потік відходів з $m$-го несанкціонованого звалища на всі полігони. 


\section{СІЛЬСЬКЕ ГОСПОДАРСТВО. ЕКОЛОГІЯ}

1. Функціонально-предметна модель регіонального відтворення природно-ресурсної бази, яка грунтується на складанні балансових схем життєвого циклу сировини та енергії у замкнутому циклі використання матеріально-енергетичних ресурсів регіону та їх економіко-математичного опису, включає матеріальні та енергетичні потоки на стадіях виробництва, споживання, поводження з потенційними та непотенційними вторресурсами, асиміляції відходів навколишнім середовищем

\section{2. Обмеження у системі управління ТВ:}

- не лімітована система управління ТВ;

- економічно лімітована система управління ТВ;

- транспортне лімітування системи управління ТВ;

- технічне лімітування системи управління ТВ;

- рециркуляційне лімітування системи управління ТВ;

- змішане лімітування системи управління ТВ.

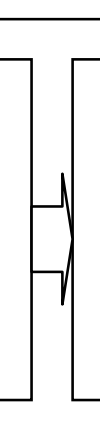

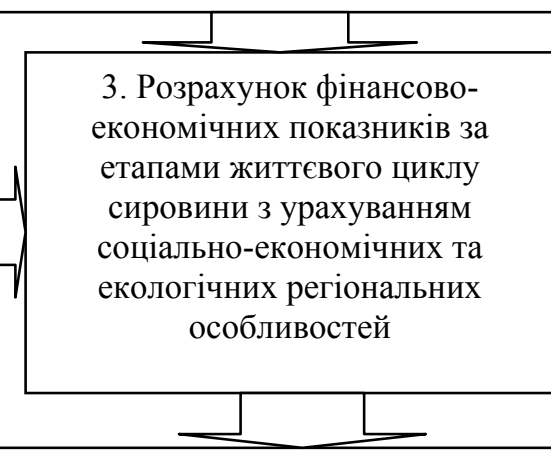
етапами життєвого циклу сировини з урахуванням соціально-економічних та особливостей

4. Імітаційна модель управління ТВ: $X=\Phi(X, Y)$, за умови $-X \leq X^{m}, Y \leq Y^{m}$,

- множина змінних стану системи управління ТВ; $Y=\left\{\alpha_{g}, \beta_{p}, \ldots, \tau^{T}\right\}$ - множина параметрів стану даної системи у регіоні; $X^{m}, Y^{m}$ - множина обмежень на змінні та параметри стану даної системи у регіоні; $\Phi$ - лінійний функціонал, який пов'язує значення змінних стану між собою за заданих параметрів стану системи

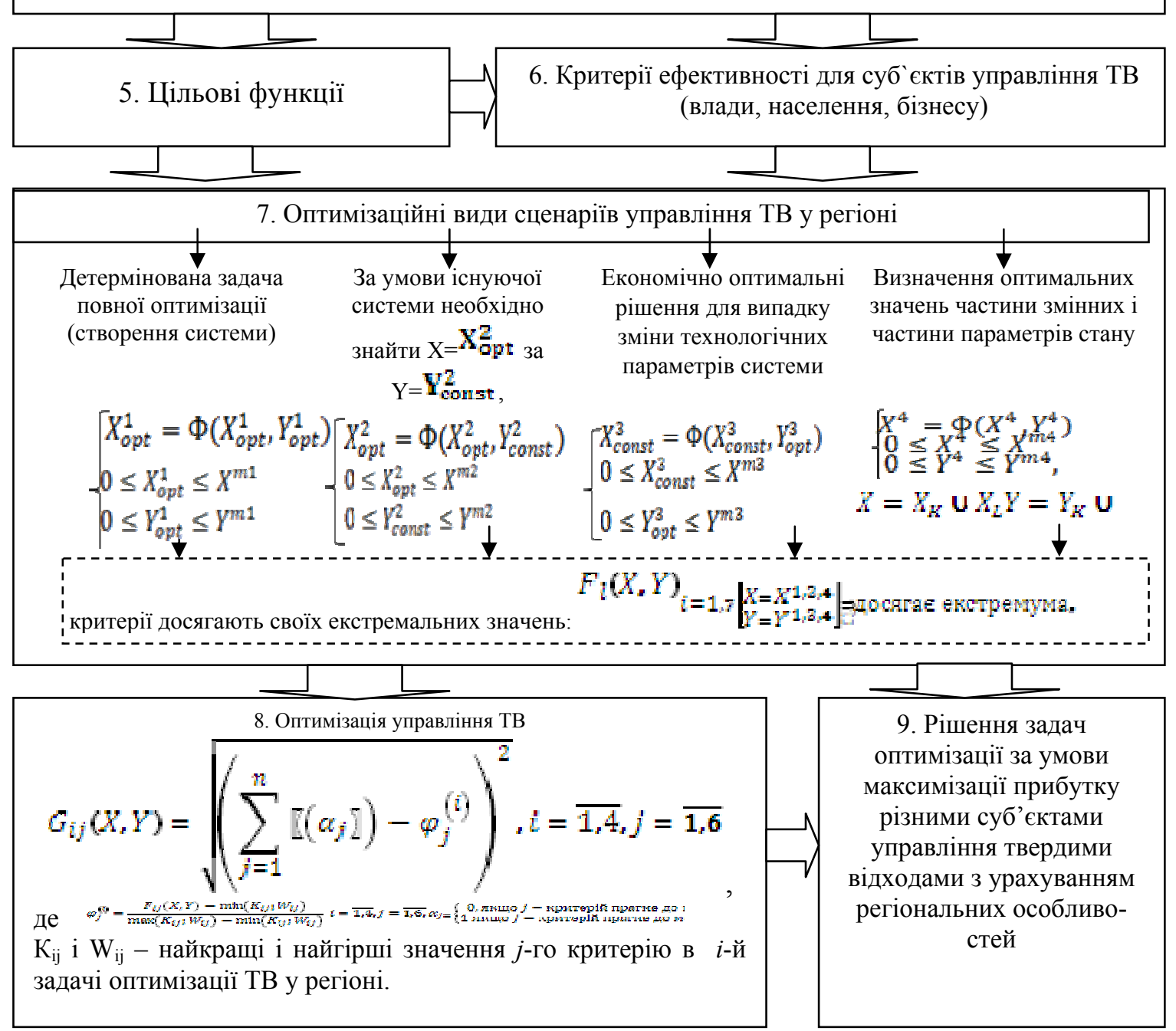

Рис. 2. Оптимізаційна модель управління твердими відходами у регіоні (розроблено авторами) 


\section{СІЛЬСЬКЕ ГОСПОДАРСТВО. ЕКОЛОГІЯ}

Видалення відходів у регіоні можливе на полігони відходів, санкціоновані звалища (що $є$ небажаним) і несанкціоновані звалища (що $є$ забороненим). Вторинні ресурси переробляються та повертаються у регіональні ресурси, заміщуючи первинну сировину. Розрахунок отримання вторинних матеріальних i енергетичних ресурсів 3 метою економії енергетичних ресурсів регіону наведено у роботі [5]. У загальному вигляді економічний збиток за забруднення довкілля ТВ наведено у монографії [6].

Таким чином, побудова оптимізаційної моделі управління ТВ у регіоні передбачає аналіз матеріальних та фінансових потоків у даній системі 3 урахуванням можливих методів i технологічних рішень їх реалізації на всіх етапах життєвого циклу сировини (від вилучення до асиміляції довкіллям), цільовою функцією для якої виступає багатокритеріальна функція управління, а формалізація задається імітаційною моделлю з урахуванням обмежень технічного, транспортного, рециркуляційного та економічного характеру у регіоні, та яка включає визначення динамічних режимів оптимального управління ТВ за досягнення цільовими критеріями своїх екстремумів (рис. 2). Дана модель побудована за критеріями: мінімізація утворення відходів $F_{l}(X)$; максимізація сортування і переробки відходів $F_{2}(X)$; мінімізація збитку за забруднення довкілля та ризиків здоров'ю населення від поводження з $\mathrm{TB} F_{3}(X)$; максимізація прибутку від реалізації вторинних ресурсів $F_{4}(X)$; мінімізація витрат на систему $F_{5}(X)$; максимізація прибутку від функціонування системи управління ТВ для регіону $F_{6}(X)$.

У загальному вигляді задача оптимального управління ТВ регіону являє собою детерміновану задачу повної оптимізації: знайти множину змінних (X) і параметрів (У) стану оптимуму системи $\left(X=X_{\text {opt }}^{1}, \quad Y=Y_{o p t}^{1}\right), \quad$ за яких $X_{o p t}^{1}=\Phi\left(X_{c p t}^{1}, Y_{c p t}^{1}\right), 0 \leq X_{o p t}^{1} \leq X^{m 1}$ $0 \leq Y_{o p t}^{1} \leq Y^{m 1}$, а критерії оптимізації досягають своїх екстремумів $F_{1}(X, Y) \rightarrow \min ; F_{2}(X, Y) \rightarrow \min$; $F_{3}(X, Y) \rightarrow \max ; \quad F_{4}(X, Y) \rightarrow \max ; \quad F_{5}(X, Y) \rightarrow$ min; $F_{6}(X, Y) \rightarrow \max$ за $X=X_{o p t}^{1}, Y=Y_{o p t}^{1}$.

За умови існування певної системи поводження 3 ТВ у регіоні, тобто коли параметри задані $\left(Y=Y_{\text {const }}\right)$ і постійні протягом певного проміжку часу, оптимізаційна задача зводиться до не- обхідності знайти $X=X_{\text {opt }}^{2}$ за умови $Y=Y_{\text {const }}^{2}$, а множина критеріїв досягає своїх екстремальних значень. Рішення, які отримуються в кінці, надають інформацію про найбільш оптимальне управління матеріальними і фінансовими потоками за вже існуючої системи.

Якщо $X=X_{\text {const }}^{3}$, то необхідно визначити оптимальні значення параметрів системи $Y=Y_{o p t}^{3}$, а множина критеріїв досягає своїх екстремальних значень. Цей тип задачі дає можливість одержати інформацію про економічно оптимальні рішення для випадку зміни технологічних параметрів системи поводження з ТВ. Якщо необхідно визначити оптимальні значення частини змінних i частини параметрів стану в разі заданих значень інших змінних і параметрів стану, тобто $X=X_{K} \cup X_{L}$ та $Y=Y_{K} \cup Y_{L}$, де $X_{K}, Y_{K}-$ змінні i параметри оптимізації системи, а $X_{L}, Y_{L} \in$ константами, то $X^{4} \in X_{K}$, то $X^{4}-X_{o p c}^{4}, X^{4} \in X_{L}$, то $X^{4}=$ const $X_{L} ; \quad Y^{4} \in Y_{E}, \quad$ то $Y^{4}=Y_{o p t}^{4}, \quad Y^{4} \in Y_{L}, \quad$ то $Y^{4}=$ const $Y_{L}$. Цей тип задач використовується, як правило, для вирішення задач з метою оптимального включення в існуючу систему поводження із ТВ додаткових ланок або циклів.

Очевидно, що в разі вибраних лінійних критерій оптимізації та лінійній системі зв'язку змінних у розрахунковій схемі, ми отримаємо класичну задачу лінійного програмування (і квадратичного програмування для багатокритеріальних задач). При цьому як єдиний інтегральний критерій у процесі вирішення задач оптимізації управління ТВ може використовуватися сума квадратів відхилень нормованих цільових функцій $\left(F_{j}, j=\overline{1,6}\right)$ від своїх максимальних i мінімальних значень.

Для виявлення загальних залежностей рішень задач управління ТВ сформовано аналітичні рішення однокрокових детермінованих задач оптимального управління, на основі заміни лінійноломаної залежності інтегрального потоку ТВ на нелінійну неперервну функцію (математичний опис приведений авторами в [7]). Дані залежності дають змогу розраховувати оптимізаційні характеристики управління твердими відходами для різних суб'єктів управління ТВ (рис. 3). 


\section{СІЛЬСЬКЕ ГОСПОДАРСТВО. ЕКОЛОГІЯ}

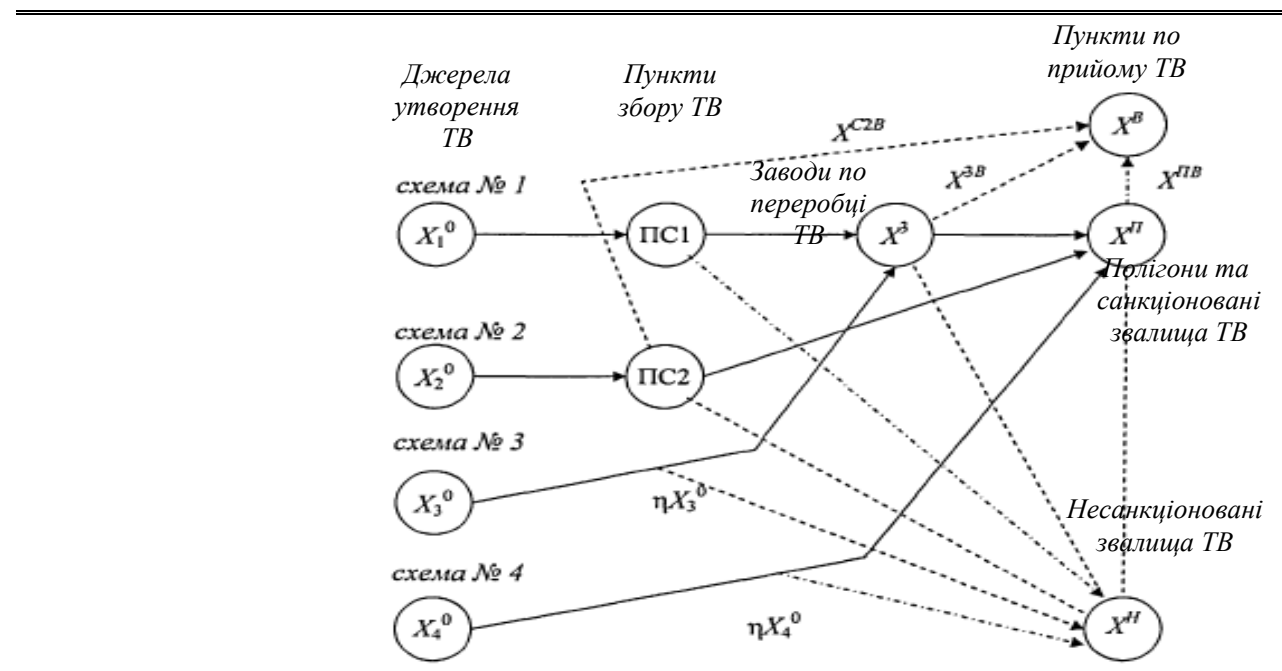

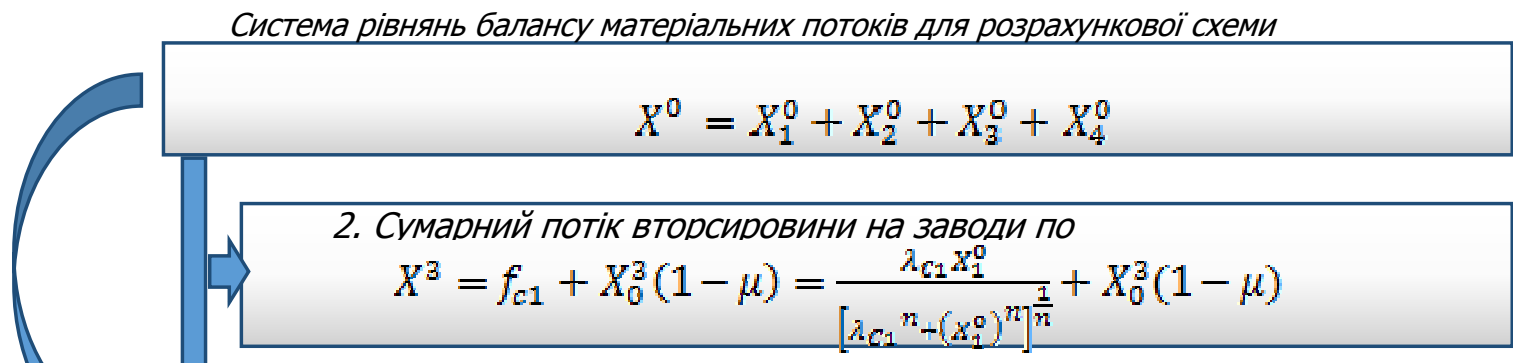

$$
\begin{aligned}
& X^{\Pi}=X^{3 \Pi}+f_{c 2}+(1-\mu) X_{4}^{0}\left(1-\beta_{4}{ }^{0} \beta_{0}\right)= \\
& =\left(1-\beta^{3} \beta_{0}\right) \frac{\lambda_{3} X^{2}}{\left[\lambda_{3}{ }^{n}+\left(X^{2}\right)^{n}\right]^{\frac{1}{n}}}+\frac{\lambda_{2} X^{c i n}}{\left[\lambda_{2}{ }^{n}+\left(X^{c 2 \Pi}\right)^{n}\right]^{\frac{1}{n}}}+\left(1-\mu X_{4}^{0}\left(1-\beta_{4}{ }^{0} \beta_{0}\right)\right. \\
& =\left(X_{0}^{2}-f_{c 1}\right)+\mu X_{2}^{9}+\left(X^{2}-f_{3}\right)+\left(X^{C n}-f_{n 2}\right)+\mu X_{4}^{0}+\left(X^{\Pi}-f_{n}\right) \\
& X^{\bar{E}}=X^{3 \mathrm{E}}+X^{\mathrm{C2E}}+X^{\mathrm{ME}}=\beta^{\mathrm{a}} \beta_{0} \frac{\lambda_{3} X^{3}}{\left[\lambda_{8}{ }^{n}+\left(X^{\mathrm{E}}\right)^{\mathrm{n}}\right]^{\frac{1}{\mathrm{n}}}}(1-\mu)+\alpha_{2}{ }^{\mathrm{C}} \beta_{2}{ }^{\mathrm{C}} \beta_{0} \mathrm{X}_{2}^{0}+(1-\mu) \beta_{4}{ }^{0} \beta_{0} \mathrm{X}_{4}^{0}
\end{aligned}
$$

\section{4. Сумарний потік ТВ на несанкціоновані}

\section{Рис. 3. Розрахункова балансова схема інтегральних потоків ТВ у регіоні (розроблено авторами з використанням [5])}

На рисунку 3 прийняті наступні позначення: $X_{1}^{O}, X_{2}^{O}, X_{3}^{O}, X_{4}^{O}$ - інтегральні потоки потенційних та непотенційних вторресурсів на вході кожної зі схем утилізації ТВ; $\beta_{0}, \beta_{2}{ }^{\mathrm{C}}, \beta_{3}^{\circ}, \beta_{4}^{\circ}-$ середньозважені коефіцієнти вмісту вторинних ресурсів у ТВ $\left(\beta_{0}\right)$, іх вилучення на ПС 2 власниками ТВ $\left(X_{3}^{O}, X_{4}^{o}\right)$ відповідно; $X^{3 \mathrm{~B}}, X^{\mathrm{C} 2 \mathrm{~B}}, X^{\text {ПВ }}$ інтегральні потоки вторсировини, які поступають на комплексні приймальні пункти вторинних ресурсів; $\mu_{-}$коефіцієнт несвідомості «вла- сників ТВ», що визначає долю відходів, які власник направить на несанкціоноване видалення 3 метою отримання «уявного» прибутку; $X^{\mathrm{O} H \mathrm{H}} X^{04 \mathrm{H}}, X^{\mathrm{O} 1 \mathrm{H}}, X^{\mathrm{O} 2 \mathrm{H}}, X^{3 \mathrm{H}}, X^{\mathrm{IH}}-$ втрати вторсировини, що обумовлені об'єктивними i суб'єктивними факторами системи поводження 3 ТВ у регіоні.

Практичне використання оптимізаційної моделі можна представити на прикладі Полтавської області. У Полтавській області щорічно утворюється близько 480 тис. т (1,6 млн м³) твердих побутових відходів, які видаляються на 377 сан- 


\section{СІЛЬСЬКЕ ГОСПОДАРСТВО. ЕКОЛОГІЯ}

кціонованих полігонах та звалищах ТВ та 4,5 млн т промислових відходів (з яких 200 тис. т небезпечні відходи) [4]. Середній рівень використання відходів у якості вторинних ресурсів у промисловості становить близько однієї третьої (близько $30 \%$ ), а побутових відходів - близько 8 \% від загальної маси [2].
Враховуючи регіональні особливості Полтавської області [9], можна виділити наступні цільові функції оптимізаційного управління ТВ (прийняті обмеження рециркуляційного характеру):

- екологічний ризик здоров'ю населення від сфери поводження 3 TВ:

$$
\begin{aligned}
& V=\sum_{n=1}^{N} Y_{n} \cdot R_{n}=\left(\sum_{n=1}^{N} 1-\exp \left(\ln (0.04)\left[\frac{c}{\mathrm{r} g R \cdot K_{g}}\right]^{b}\right\}\right)=\left(\gamma \sum _ { i = 1 } ^ { n } \left[\sum_{j=1}^{J} \delta_{j} \cdot\right.\right. \\
& \left.\sum_{i=1}^{I}\left(\sum_{k=1}^{L} V_{k} M_{k} e^{n t}\right) \cdot c_{i} a_{i}\right]+\varphi \sum_{i=1}^{I} a_{i} b_{i}(l-E-\mu W) \cdot C_{i}+(B P+P P) \rightarrow \min
\end{aligned}
$$

де $Y_{n}$ - економічний збиток за забруднення довкілля від поводження $3 \mathrm{~TB}$, грн.; $R_{n}-$ ризик здоров’ю населення від поводження 3 ТВ; $C-$ середня концентрація речовини, що надходить в організм людини протягом його життя; $K_{e}-$ коефіцієнт небезпеки, який визначається залежно від класу небезпеки речовини; $b$ - коефіцієнт ізоефективності; $\gamma, \varphi$ - константи, чисельне значення якої встановлюється 3 урахуванням інфляції; $\delta_{j}$ - коефіцієнт відносної небезпеки забруднення атмосферного повітря над територіями різного типу $j ; V_{k}$ - теоретичний потенціал утворення метану 3 органічної складової ТВ, м³/piк; $M_{k}$ - маса органічної складової у загальному обсягу ТВ, т/т; $h$ - константа утворення метану 3 органічних ТВ; $t$ - час 3 моменту відкриття полі- гону, років; $C_{i}$ - масова доля і-ї шкідливої речовини у загальному обсязі біогазу (фільтраті); $a_{i}$ - показник відносної агресивності $i$-ї шкідливої речовини; $b_{i}$ - показник відносної екологічної небезпеки скиду шкідливих речовин у водойми; $l$ - загальний об'єм притоку води, м³/piк; $E$ - об'єм випаровування та транспірації води, $\mathrm{m}^{3} /$ рік; $\mu$ - поглинаюча здатність ТВ; $B P-$ недоотриманий прибуток регіону від вилучення земель під об'єкти поводження з ТВ із господарського обігу, грн.; $P P$ - втрати від забруднення земель, грн.

- максимамізація прибутку в разі мінімальних вкладень у дану сферу:

$D=2_{t=0}^{T} \mathrm{l}\left(\theta_{t}+U_{t}-\sum_{t=1}^{T}\left[\frac{1}{(1+i)^{t}}-\left(A_{t}-X_{t}+B_{t}-Y_{t}+C_{t}^{T}-Z_{t}+E_{t}+F_{t}\right)-\mathrm{H}_{3 t}\right) \rightarrow \max \right.$,

де $U$ - прибуток від переробки ресурсоцінних фракцій, грн.; $\theta$ - плата за приймання відходів, грн.; $i$ - ставка дисконтування; $t$ - періоди функціонування сфери поводження 3 TВ, рік; $A$ - витрати на переробку, за вирахуванням прибутку від продажу ресурсоцінних фракцій, грн./т; $B$ - витрати на збір і транспортування ТВ, грн./т; $C$ - витрати на захоронення ТВ, грн./т; $X$ - маса ТВ, що надходить на переробку, т; $Y$ - маса ТВ, яка транспортується на полігон, т; $Z$ - загальний обсяг ТВ, що видаляється, та залишок від переробки, т; $E, F$ - витрати на відкриття переробного заводу (станції), полігону, грн;

- вартість земель, що виводяться із сільськогосподарського обігу внаслідок забруднення, грн.;

- енергоємність сфери поводження з ТВ (розрахунок наведений у [8]).

Результати інтегрального моделювання для п’яти сценаріїв модернізації системи поводжен- ня $з$ ТВ для задачі пошуку $X=X_{\text {const }}^{3}$, за $Y=Y_{\text {opt }}^{3}$, (множина критеріїв досягає своїх екстремальних значень) представлені на рисунку 4.

Висновок. На основі розробленої балансової схеми життєвого циклу твердих відходів у регіоні науково обгрунтовано оптимізаційну модель управління сферою поводження з ТВ. Оскільки множина $\mathrm{X}$ ширша, ніж множина зв'язків у функціоналі $\Phi$, то розроблена модель має множину допустимих рішень і відповідно пропонує вибір найкращого 3 них з урахуванням цільових функцій. Таким чином, розроблена модель дає змогу вирішувати поставлені задачі оптимізації розвитку сфери поводження із ТВ у випадку заданої множини змінних і параметрів стану системи для конкретного типу життєвого циклу відходів. Очікуваними результатами реалізації оптимізаційних стратегій $є$ комплексне рішення економічних, соціальних та екологічних завдань регіону, забезпечення економного використання ресурсів регіонів України. 


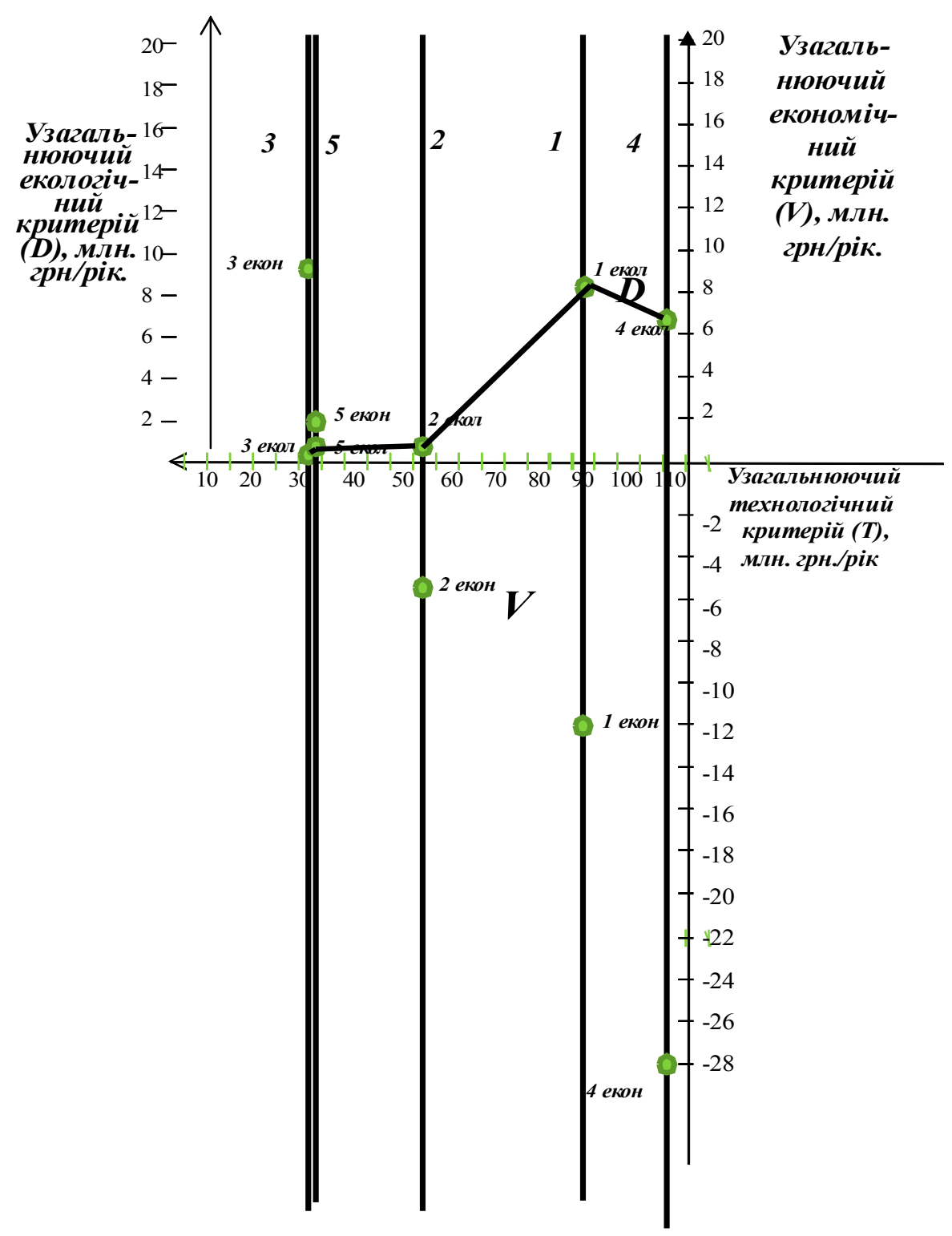

Рис. 4. Оптимізація узагальнюючих критеріӥв різних технологічних рішень управління ТВ на прикладі Полтавської області (складено авторами)

Наведена оптимізація узагальнюючих критеріїв управління ТВ на прикладі Полтавської області дала змогу зробити висновок, що з економічної, екологічної та технологічної точок зору найбільш ефективним рішенням $є$ третій сценарій, а саме: будівництво чотирьох сміттєпереробних заводів (сумарна потужність 1,2 млн м ${ }^{3}$ ) та 7 полігонів ТВ потужністю по 50 тис. т, в разі якого забезпечується мінімальний економічний ризик, а щорічний економічний ефект становить

\section{БІБЛІОГРАФІЯ}

1. Вагин В. С. Комплексное управление жизненным циклом ТБО в регионе: понятийнотерминологические и методологические основы
9,88 млн гривень. Найбільш ризикованим і небезпечним для здоров'я населення, а також найбільш витратним є будівництво сміттєспалювальних заводів, тобто четвертий сценарій $є$ неприйнятним для області. Існуюча ситуація, хоча i характеризується найменшими витратами, $€$ неприйнятною, оскільки характеризується найбільшими екологічними ризиками (9,58 млн гривень).

концепции : монография / В. С. Вагин. - Ростовн/Д : из-во СКНЦВШ, 2004. - 111 с. 


\section{СІЛЬСЬКЕ ГОСПОДАРСТВО. ЕКОЛОГІЯ}

2. Довкілля Полтавщини : монографія / [Голік Ю. С., Ілляш О. Е., Самойлік М. С. та ін.]. Полтава : Копі-центр, 2014. - 256 с.

3. Онищенко В.O. Теоретико-методологічні засади управління сферою поводження 3 твердими відходами на регіональному рівні: монографія / В. О. Онищенко, М. С. Самойлік. Полтава : ПолтНТУ, 2013. - 524 с.

4. Регіональна програма охорони довкілля, раціонального використання природних ресурсів та забезпечення екологічної безпеки з урахуванням регіональних пріоритетів Полтавської області / [Онищенко В. О., Голік Ю. С., Ілляш О. Е. та ін.]. - Полтава : Полтавський літератор, 2012. $-164 \mathrm{c}$.

5. Самойлік М. С. Біоенергетична оцінка сфери поводження $з$ твердими відходами на регіональному рівні / М. С. Самойлік // Вісник Житомирського національного агроекологічного університету. - 2013. - №1-2 (37). - Том 2. C. $340-349$.
6. Самойлік M. С. Еколого-економічна оцінка забруднення навколишнього середовища в системі екологічно безпечного розвитку регіонів України : монографія / М. С. Самойлік, С. В. Онищенко. - Полтава : ПолтНТУ, 2012 $269 \mathrm{c}$.

7. Самойлік M. С. Економіко-екологічні оптимальні стратегії управління системою поводження 3 твердими відходами регіону / М. С. Самойлік // Проблеми економіки. - 2014. №1. - C. 343-349.

8. Самойлік М. С. Еколого-енергетична оцінка життєвого циклу твердих відходів на регіональному рівні / М. С. Самойлік, П. В. Писаренко // Науковий вісник Національного університету біоресурсів і природокористування України. Серія «Економіка, аграрний менеджмент, бізнес». - 2014. - Вип. 200. - Ч. 1. - С. 267-275.

9. Самойлік М. С. Ресурсно-екологічна безпека регіону : монографія / М. С. Самойлік. - Полтава : Сімон, 2014. - 317 c. 